\title{
ТЕОРЕТИЧНА МОДЕЛЬ ІСТОРИЧНОГО НАРРАТИВУ
}

\author{
о.В. Мішалова
}

\section{1 Проблема історичного нарративу}

Поняття нарративу у сучасній філософії історії $є$ достатньо широким, що обумовлюеться його неоднозначним тлумаченням представниками різних течій та напрямків. Узагальнюючи, можна умовно визначити декілька рівнів його концептуалізації: по-перше, історичний нарратив як синонім історичного тексту, тобто окремої праці з історії; по-друге, «майстер-нарратив» - певна парадигма або підхід до розгляду історичної проблематики (наприклад, через мотив класової боротьби в марксизмі); по-третє, «великий нарратив» як варіант всеохоплюючої, єдиної універсальної історії людства (наприклад, біблейський сюжет чи проект всесвітньої історії). Саме в останньому розумінні нарративи досить категорично критикуе Ж.-П. Ліотар, підкреслюючи, що наш час $є$ часом скептицизму, недовіри до великих нарративів («криза розповідей»), які легітимізують глобальні концепції історії [11, с. 9-10].

Важливо враховувати також два різних поняття нарративності в самій нарратології (теорії оповіді). Перше з них сформувалося ще у класичній нарратології, де оповідання протиставлялося безпосередньому драматичному виконанню і пов'язувалося з обов'язковою наявністю в тексті чітко вираженого голосу оповідача (нарратора), посередника між автором та оповідним світом. Присутність оповідача вважається головною рисою оповідного твору. Друге поняття нарративності походить із структуралістської нарратології, відповідно до якої вирішаль-

Aктуальні проблеми духовності

(Відн. ред.: Я.В. Шрамко)

Крнвай Pir (2008), 34-47 
ним в оповіданні $\varepsilon$ не наявність опосередковуючої інстанції викладення, а певна структура викладеного матеріалу. Структуралістська нарратологія, що склалася на Заході у 1960-ті роки, ставить собі за мету відкриття загальних структур всіх можливих нарративів, тобто оповідних творів будь-якого жанру і функщіональності [23, с. 10-13].

В даній роботі під історичним нарративом розуміється оповідний історичний текст i, виходячи із структуралістського поняття нарративності, здійснюеться спроба окреслити його теоретичну модель.

Використання пізнавальних моделей-характерна риса сучасної науки. Когнітивна модель являе собою евристичний конструкт, який використовується для полегшення емпіричних досліджень та комунікації вчених, а також для організації існуючої літератури і стимуляції подальших досліджень. Модель служить найбільш зручною (на певному етапі дослідження) системою узагальнення емпіричних даних та теоретичних уявлень стосовно предмету вивчення. При появі нових гіпотез чи експериментальних даних створюються нові моделі, які $\epsilon$ більш загальними порівняно з попередніми або зображують об'єкт дослідження 3 іншої сторони. 3 розвитком когнітивних наук (міждисциплінарного підходу, що об'єднує дослідників сфери пізнання, головним предметом уваги яких $є$ питання закономірностей отримання, перетворення, представлення або репрезентування, збереження та відтворення інформації) застосування моделей широко впроваджується і в гуманітарних дослідженнях. Тут виділяють наступні особливості когнітивних моделей: істотно менша структурна чіткість, оскільки модель не претендуе на онтологічний опис об'єкту, а лише представляе його у відповідному контексті і повинна «працювати» аналогічно функціонуванню об'єкту; міждисциплінарний характер, що пояснюе використання ними метафор та аналогій із самих різних областей науки, мистецтва, практичної діяльності; часто мають характер узагальненої схеми відповідного об'єкту, корисної для подальшого його вивчення $[1$, с. 149 , $154-155]$.

У філософії історії другої половини ХХ ст. було запропоновано ряд теоретичних моделей історичного нарративу, серед яких ми коротко розглянемо різко відмінні між собою концепції А. Данто, Х. Уайта та А. Мегілла.

А. Данто створюе надзвичайно докладну теорію історичного тексту. На його думку, будь-який нарратив (оповідь) - це структура, яка накладається на події, поєднуючи одні та виключаючи інші як такі, що не мають значення [7, с. 129]. Логічно в оповіді можна виділити початок, середину та кінець. Одне з основних завдань нарративу по- 
лягає у характеристиці арени дійства, яке призводить до закінчення, а опис останнього слугує поясненням зміни, крайніми точками якої $€$ початок та кінець оповіді [7, с. 234-235].

Нарратив в історії $е$ способом організації минулого у часові цілісності з метою його пояснення. Будуються історичні нарративи переважно із нарративних речень (такі, що посилаються на дві розділені у часі події та описують більш ранне 3 них через посилання на більш пізне; щоб вважатись істинними, вони повинні логічно передбачати, що обидві події дійсно мали місце) [7, с. 160], позначаючих конструкцій (виразів на зразок «місце, де...», «людина, яка...», які дозволяють унікальним чином виділити конкретні події, осіб та місця завдяки використанню відносних займенників, займенникових прислівників) $[7$, c. 1653] та часових структур, в які історик поєднує окремі події за своїм критерієм значимості (наприклад, «Велика французька революція») [7, с. 161]. Підсумовуючи, можна говорити, що А. Данто пропонуе теоретичну модель («каркас») будь-якого нарративу, більш детально досліджуючи специфічні риси історичних нарративів.

Цікаву концепцію будови історичної оповіді висунув Х. Уайт. Відповідно до його теорії, історичний нарратив $є$ певною комбінацією сюжетної лінії (за аналогією з літературою: роман, комедія, трагедія, сатира), типу пояснення (формалістичне, механістичне, органічне, контекстуальне) та ідеологічного обгрунтування (з позицій анархізму, радикалізму, консерватизму, лібералізму). На думку Х. Уайта, історик від самого початку обирає інтерпретативну стратегію або троп (метафора, метонімія, синекдоха, іронія), який чітко задае зазначені параметри історичної оповіді. «В історії ... історичне поле конституюється як можлива сфера аналізу в мовному акті, тропологічному за своєю природою. Домінантний троп, згідно 3 яким цей конституюючий акт доводиться до кінця, буде визначати і види об'єктів, яким дозволено з'являтись у цьому полі в якості даних, і можливі співвідношення, які, як передбачається, існують між ними» [21, с. 496-497]. Х. Уайт підкреслюе самодостатність історичних нарративів, можливість іхнього аналізу поза контекстом, оскільки свій контекст вони несуть в собі $[8$, c. 144]. Отже, Х. Уайт надае більш розгорнуту модель праці з історії, виділяє декілька показників її будови i, хоча він робить свій висновок на основі аналізу історичних праць XIX ст., запропоновану схему можна застосовувати у дослідженні будь-якого історичного нарративу.

Функціональною можна назвати «категоріальну схему» аналізу історичних праць А. Мегілла. Він вирізняє чотири основні завдання історіографії: опис, пояснення, аргументація та інтерпретація. В залежно- 
сті від того, яке 3 них превалюе в тій чи іншій роботі історнка, вона може відповідати формі нарративу або відхилятися від неі, хоча всі 3 названих функцій обов'язково присутні у кожному історичному дослідженні. Нарративом, за А. Мегіллом, е праця, в якій «історичні дії, події, герої та оточення будуть відігравати (але в різних пропорціях) істотну роль в тексті» $[13$, с. 241]. Це робота, в якій саме опис певного аспекту історичної реальності - розповідь про те, що мало місце - домінує, є головним завданням. Праці, в яких історик більше концентрується на поясненні (тобто на зв'язку експаланса та експаландума, хоча нарратив і не відкидає останнє), аргументації (зосередження уваги на коментуванні, аналізі текстів джерел, в результаті чого нарративні речення про минуле відходять на задній план, а елементи нарративу, тобто події, герої, оточення скоріше передбачаються, ніж прописуються) чи інтерпретації (історик перетворюеться на суспільного або інтелектуального критика) можуть істотно відходити від форми нарративу. На думку А. Мегілла, кордони категоріальної схеми необхідно враховувати, оскільки визначені категорії складають карту важливих вимірів історіографічної роботи, є достатніми для повного аналізу праць з істоpiї [13, с. 241-243]. Таким чином, А. Мегілл, вирізняючи чотири можливі моделі історичного дослідження, істотно звужує поняття нарративу до розповіді, зводить його лише до одніеї з них.

На нашу думку, можна запропонувати більш узагальнену схематичну модель історичного нарративу з наступними параметрами:

- смислова структура, відповідно до якої організовується історичний матеріал;

- літературна форма, корелятивна змістовній структурі;

- точка зору або оцінка, яка визначає перспективу дослідження.

Розглянуті параметри інваріантні для будь-якого історичного нарративу в цілому, набуваючи специфічних особливостей та характеристик відповідно до конкретного часу і місця його створення.

\section{2 Смислова структура}

Смислова структура нарративу відіграє організуючу роль у двох, певною мірою незалежних, площинах: по-перше, вона задае формальну 
єдність історичного матеріалу, співвідносячись з композиційною будовою будь-якої оповіді ( «початок-середина-кінець»); по-друге, відповідає певному способу організації минулого чи сюжетній лінії, яка розгортається в межах композиційної схеми і забезпечуе унікальну смислову зв'язаність матеріалу у конкретному історичному творі.

Композиційна будова $з$ чітко визначеними початком, серединою та кінцем $е$ формальною характеристикою історичного нарративу або історії (story). Так, хроніка може не мати зав'язки, оскільки починається тоді, коли їі автор приступае до запису подій. Крім того, кінець хроніки залишається завжди відкритим, вона не потребує розв'язки чи кульмінації, тому що може продовжуватися безкінечно. Порівняно 3 хронікою історична оповідь має чітко визначену форму [21, с. 26].

Текст, за визначенням, має кордони (початок-кінець), однак в кожній конкретній праці вони наділяються різною моделюючою вагою. Вирізняють тексти орієнтовані на початок (надають йому особливу семіотичну значимість) та такі, що більше скеровані на кінець. Прикладом перших є есхатологічні міфи й середньовічні тексти. Історична оповідь і пов'язана з нею структура романного тексту, підвладні часовій та причинно-наслідковій послідовності, орієнтовані на кінець тексту. У ньому, за Ю.М. Лотманом, зосереджується основний структурний смисл оповіді $[12$, с. 355,358$]$. Важливу роль категорії «кінець» підкреслював також А. Данто, на думку якого наш вибір початку оповіді визначається її завершенням, оскільки початок описується із посиланням на її кінець $[7$, с. 234].

Другою важливою функцією смислової структури нарративу - забезпечення смислової єдності історичного матеріалу. Простий перелік фактів не є оповіддю. Смислова зв'язаність оповідних сегментів створюе сюжет, який, як підкреслюе Ю.М. Лотман, являе собою такий же закон нарративного тексту, як синтаксичний зв'язок - закон побудови правильної фрази. Події реального життя, що наповнюють деякий просторово-часовий континуум, «нарративний текст витягуе в сюжетно-лінійну побудову» $[12$, с. $340-341]$.

Зі смисловою структурою можна співвіднести поняття сюжету, тип побудови сюжету (emplotment) Х. Уайта. На його думку, сюжет привносить смисл в історію (story). Кожна історія (history), навіть найбільш синхронна або структурна, перетворюеться на історію (story) за допомогою сожету. X. Уайт вирізняє чотири основні способи його побудови та репрезентації історії (Роман, Комедія, Трагедія, Сатира). Важливим $є$ той факт, що саме історик визначае і обирає тип сюжету. «Якщо історик в ході своєї розповіді історії надає ій сюжетну стру- 
ктуру Трагедії, він «пояснив» їі одним чином; якщо він структурував iі як Комедію, він «пояснив» 111 іншим чином. За допомогою побудови сюжету послідовність подій, яка формуеться в історію (story), розкривається поступово як історія (story) визначеного типу» $[21$, c.27]. 3 точки зору П. Рікьора, важливим е те, що поняття сюжету у Х. Уайта має точний і обмежений зміст: воно не вичерпуе собою нарративну структуру в цілому, хоча й являе собою їі стрижень $[19$, с. 192].

П. Рікьор передає термін «сюжет» (emplotment) словом «інтрига» та говорить про інтригу в широкому розумінні. Остання $є$ впорядкуванням фактів (послідовність речень, які позначають дію) у цілісну дію, що конституюе розказану історію, становить літературний еквівалент синтагматичного порядку (order), який вноситься до практичного поля завдяки оповіді [19, с.70]. П. Рікьор вважає, що інтрига виявляє осмислену історію в ряду подій або перетворюе їх на історію, що у будь-якому разі характеризуе інтригу як посередницю між подіями i розказаною історією. На думку П. Рікьора, інтригу можна назвати синтезом різнорідного [19, с. $80-81]$, вона «зводить разом» та поєднуе в цілісну завершену історію різнорідні розрізнені події, схематизуючи таким чином інтелігібельне значення, яке пов'язуеться 3 розповіддю, взятою як ціле $[19$, с. 8].

В обгрунтуванні організуючої ролі «інтриги у широкому розумінні», яка характерна як для подієвої, так і для структурної історіi, П. Рікьор спирається на міркування свого співвітчизника П. Вейна. Останній відстоюе досить крайню позицію, проголошуючи історію мистецтвом, а не наукою, навіть гуманітарною. Головна відмінність історія розглядае все, що трапилось, як варте уваги: вона не має права обирати, обмежуватися лише тим, що має наукове пояснення. В результаті наука порівняно з історією бідніша та страшенно повторюеться [5, с. 303].

Історія (story) - розповідь про події, «викладення, і воно дозволяє встановити деякі хибні проблеми. Як і роман, історія розбирає, спрощуе, організовуе, вміщае ціле століття на одній сторінці» [5, с.8]. Однак, історія - розповідь про дійсні події. Для того, щоб вважатись історичним, факт, в межах цього визначення, повинен відповідати лише одній умові: відбутися насправді. Факти існують лише в інтригах та завдяки ним, «отримуючи в них відносне значення, яке їм приписує (людська) логіка театральної вистави» $[5$, с. 17, 67]. Фізика підводить факти під закони, історіографія поєднуе їх в інтриги [19, с. 196]. Певною мірою синонімічно поряд 3 «інтригою» П. Вейн використовує термін «сюжет» (як вже здійснена в конкретній праці інтрига), 
свободою вибору якого володіє історик. Фактів в ізольованому вигляді не існуе, дослідник знаходить їх у формі певних сукупностей, де вони відіграють роль причин, цілей, обставин. Тому, робить висновок П. Вейн, для фактів характерна природна й незмінна структура (об'єктивний взаємозв'язок), яку історик знаходить вже в готовому вигляді, як тільки обирає сожкет. Завдання історика-виявлення цієї структури [5, с. 41-42]. Варто підкреслити, що позиція П. Вейна також співзвучна концепції X. Уайта і певною мірою співвідносна з думками Р.Дж. Коллінгвуда та А. Данто щодо організуючої ролі певної смислової структури, яку застосовуе дослідник у роботі з історичним матеріалом.

Р.Дж. Коллінгвуд називае останню мережею, сконструйованою апріорною уявою історика й «натягнутою» між певними зафіксованими точками - представленими в його розпорядження свідоцтвами джерел. Ії достовірність не грунтується на фактичних даних, вона сама відіграє роль критерія їхньої істинності. Картина минулого, що належить історику та являє собою продукт його апріорної уяви, визначає вибір джерел, які він залучае до своєї роботи. Вони розглядаються в якості джерел лише тому, що обгрунтовані таким чином $[10$, с. 231,233$]$. Важливо підкреслити - концепція структурного характеру апріорної історичної уяви (яка творить історичні конструкції) Р.Дж. Коллінгвуда [10, с. 233] певною мірою співпадає з позицією П. Рікьора, який підкреслюе синтезуючу функцію продуктивної уяви, за допомогою якої здійснюеться акт конфігурації, твориться інтрига $[19$, c. 84$]$.

А. Данто наголошуе на тому, що історик за суттю своеї діяльності повинен більше прагнути до певної організації минулого, а не до його відтворення. Зазначена обставина не залежить від професійних інтересів історика, а лише доводить історичний релятивізм. Відмінність між історією та наукою, за А. Данто, полягає не у тому, що перша використовує організуючі схеми, які виходять за межі даного, а друга ні. Вони застосовуються в обох сферах і різняться лише за своїм видом. «Історія розповідає історіі» [7, с. 109].

Таким чином, чітка смислова структура $\epsilon$ важливим параметром теоретичної моделі історичного нарративу (оповіді). Вона забезпечуе подвійну організацію історичного матеріалу: композиційну (формальну) та смислову. Організуючу роль смислової структури дуже схоже визначають представники різних напрямків у сучасній філософії історії, хоча її саму в залежності від приналежності до континентальної чи англосаксонської традиції називають по-різному (сюжет, інтрига 
або конструкція, схема).

\section{3 Літературна форма}

Літературна форма історичного нарративу також здійснюе подвійну організуючу функцію: вона є засобом текстуального оформлення (матеріалізації) та подачі історичного матеріалу.

Історія «літературна» за фактом свого існування, тобто можлива як така лише оформленою у нарратив (текст) і, відповідно, не може не дотримуватися загальних правил «написання». Х. Уайт підкреслюе, що історія залишається риторичною та літературною, оскільки продовжує використовувати звичні грамотну мову й письмо як найбільш зручні засоби представлення результатів дослідження минулого [21, c. 7]. Перетворення подій у текст означає переказ їх в системі тієї чи іншої мови, тобто підпорядкування їх певній раніше даній структурній організації. Навіть якщо з самого початку вони уявлялися хаотичними і непов'язаними між собою, будучи переказаними засобами мови, вони неминуче отримують структурну єдність. Остання, фізично приналежна лише плану вираження, автоматично переноситься й на план змісту [12, с. 339$]$.

Кожна природна мова створюе свій власний ментальний світ, задає певний спосіб світосприйняття. Ментально-семіотичний світ мови не $є$ дзеркальним відображенням позамовленнєвої дійсності: образи, концепти, міфології, створені мовою, членування нею категорій простору та часу можуть значно відрізнятися від логічно перевірених, але саме на них людина спирається у повсякденному житті [16, с. 161]. Люди живуть не лише в матеріальному чи соціальному світі, як це прийнято вважати. Значною мірою ми всі знаходимося під владою тієї конкретної мови, яка є засобом вираження в даному суспільстві. «Уявлення про те, що людина орієнтуеться у зовнішньому світі, по суті, без допомоги мови та що мова являе собою лише випадковий засіб рішення специфічних завдань мислення і комунікації, - це всього тільки ілюзія», - говорить Е. Сепір [20, с. 260]. За Б.Л. Уорфом, граматика (основа мовленневої системи будь-якої мови) не просто інструмент відтворення думок, вона сама творить думку, $є$ програмою і керівництвом мисленнєвої діяльності індивідуума, засобом аналізу його вражень та їхнього синтезу. Ми вирізняемо у світі явищ ті чи інші категорії, типи не тому, що вони самоочевидні. Навпаки, світ постає перед нами у вигляді калейдоскопічного потоку вражень, які повинні бути організо- 
вані нашою свідомістю, в основному - мовленневою системою. Люди розділяють світ, організують його в поняття і розподіляють значення так, а не інакше головним чином тому, що вони учасники «домовленості», яка визначає подібну систематизацію. Така ніким несформульована домовленість має силу лише для певного мовленнєвого колективу. Людина взагалі не змогла б говорити, якщо не приймала систематизації та класифікації матеріалу, зумовлені вказаними домовленостями $[22$, c. 98$]$.

Зазначений аспект $\boldsymbol{\varepsilon}$ важливим у методології історії, оскільки, поперше, дослідник сам належить до конкретної мовної спільноти, відповідної системи мови, яка на нього впливае; по-друге, безпосереднім предметом-засобом дослідження історика $\epsilon$ тексти (зокрема, нарративи), в яких зазначені системи відтворені. «Дві різні мови ніколи не бувають настільки схожими, щоб їх можна було вважати засобом вираження однієї й тіеї ж дійсності. Світи, в яких живуть різні суспільства, - це різні світи, а не один світ з різноманітними навішаними на нього ярликами» $[20$, с. 260$]$.

Літературна форма нарративу не лише об'єктивує, зберігає історичний досвід (інформацію), але й передає, що звертає увагу на її естетичні характеристики. На думку П. Рікьора, задоволення від пізнання це в першу чергу задоволення, отримане від тексту [19, с.61].

Істориків іноді критикують за певну байдужість щодо майстерності написання, свого літературного стилю. Так, Л. Госсман вважає, що «нам нелегко сьогодні віднайти письменника рівня Джойса чи Кафки у сучасній історіографї» (див.: [2, с. 350]). Нові історичні дослідження пропонують нову форму нарративу чи низку форм, серед яких варто виокремити наступні: мікронарратив (історична оповідь про пересічних людей в їхньому локальному оточенні); поєднання в одному нарративі подій мікро- та макрорівня; історіописання в зворотному напрямі (мета - змусити читача відчути тиск минулого на окремих осіб та групи); по-четверте, розповідь однієї історії різними способами під палітуркою одніеї книги відповідно до різних підходів до минулого. На думку П. Берка, хоча історики і не повинні займатися літературними експериментами лише тому, що вони живуть у ХХ ст., чи обов'язково наслідувати новаторські, революційні літературні техніки, деякі з експериментів сучасних письменників можуть бути корисними для істориків. Зокрема, форма діалогу, гетероголосія, прийом «невірогідного оповідача від першої особи» (за умови, що недостовірність не буде занадто прихованою) $[2$, с. $351-358]$.

Варто зазначити цікаве спостереження П. Вейна щодо порівняння 
історії царя Давіда у «Книзі Самуіла» і в праці Е.Ренана. Найбільш видима відмінність стосується не змісту й цікава не стільки історику, скільки філологу, оскільки пов'язана з мистецтвом розповіді, концепцією написання, умовностями, вибором мовленнєвих зворотів, тобто - з еволюцією літературної форми, вимогами моди. Тому текст часів Давньої Греції або Людовіка XIV важко сплутати з історичною працею XX ст., навіть якщо її зміст залишився актуальним до сьогодні $[5$, с. 271].

Новітні дослідження у нарративній філософії історії пропонують експерименти не лише з літературною формою нарративу, а взагалі із формою його представлення як такою. Загалом, нарратив, наприклад у Е. Кізера, розглядається в якості альтернативного методу, форми подачі даних, оптимальної у випадках, коли вони або занадто складні чи фрагментарні для методик опрацювання матеріалу (таблиці, графіки), або коли хронологічна послідовність, особливості й деталі $\boldsymbol{\varepsilon}$ важливим. В останньому випадку узагальнюючі методики неефективні, оскільки втрачається багато інформації [18, с. 111]. Однак насьогодні говорять про «нарративну картографію», про карту як форму представлення нарративу, пропонують використовувати з такою метою також таблиці та діаграми $[17$, с. 43]. На думку А.Е. Карімова, карта є одним 3 найбільш виразних засобів «конструювання» віртуального образу такої політичної реальності, яку в певному географічному регіоні хотілося б мати владі, оскільки політичні абстракції «накладаються» на знайому і впізнавану читачами фізико-географічну реальність (контури материків, рік, гірських хребтів). Таким чином створюеться враження, що умоглядні політичні та ідеологічні поняття (наприклад, германська раса, слов'янський світ, соціалістичний табір) мають таку ж об'єктивну реальність і непорушність, як континенти, гори та ріки. Карта представляе читачу нарратив, що надае подіям, політиці або історії необхідну владі інтерпретацію, відсікаючи небажані тлумачення. Під нарративом А.Е. Карімов розуміе сюжетно-тематичну картину, сюжетну лінію - стійке поняття, пов'язане із оповіддю, викладенням, яке використовується у гуманітарних науках $[9$, с. 45$]$.

Отже, враховуючи вищезазначене, можна говорити не про літературну, а про знакову форму об'єктивації та подачі матеріалу, корелятивну смисловій структурі нарративу. Однак більш природним та адекватним у якості параметру теоретичної моделі історичного нарративу, на нашу думку, залишаеться все ж літературне (словесне) оформлення. Тим паче, що лише після такої об'єктивації історичний матеріал стає доступним для картографування й інших методик узагальнення. 


\section{4 Точка зору або оцінка, яка визначає перспективу дослідження}

Точка зору або оцінка в історичному дослідженні асоціюеться 3 питанням його об'єктивності чи суб'єктивності. Останні однаковою мірою присутні у будь-якому нарративі. Об'єктивність - конвенційно, як дотримання загальних правил та вимог дослідницької роботи 3 метою досягнення максимальної істинності результатів. Історик претендуе на істинність. Як і романіст, він прагне побудувати осмислену картину минулого, та разом 3 тим вона повинна бути такою, що відповідає історичній дійсності [10, с. 234].

Суб'єктивність виявляє себе як певна «перед-розсудочність» історичної свідомості. Історик не може бути вільним від менталітету своєї епохи, забобонів суспільства, загальної ідеологічної парадигми, в межах якої він існуе та працюе. Історичне відношення до дійсності спирається на традицію [15, с.54-55]. Культурні традиції являють собою запас сюжетів, які можуть бути використані для організації подій в історії. Останні розповідаються в межах нарративних рамок, що визначаються культурою [6, с. 12]. За П. Рікьором, зрозуміти історію означае зрозуміти культурну традицію, з якої походить типологія інтриг $[19$, c. 71].

I. Берлін пропонуе цікаву метафору «павутина» для позначення структури загальних і конкретних переконань, яку людина приймає цілісно та не має змоги, навіть в принципі, перевірити повністю. Тому що з цієї мережі найбільш загальних положень вона починає і нею ж завершуе [3, с. 41]. В кожний момент свого життя індивід $\boldsymbol{\varepsilon}$ продуктом всього досвіду, накопиченого ним самим та отриманого від предків. Реальна людина існуе як член своєї сім'ї, своєї раси, народу, епохи; як громадянин своеї країни; як представник своєї професії. Вона надихається певними релігійними, філософськими, метафізичними й політичними ідеями, які іноді розвивае чи видозмінюе своїм власним мисленням [14, с. 141].

Наступним вазкливим моментом у розгляді ціннісної складової теоретичної моделі історичного нарративу є специфічність предмету дослідження історії. Вона має справу 3 діяльністю людей-описує обставини, в яких вони живуть, і спосіб, яким реагують на них, а також вивчає вплив системи цінностей на свідомі дії людини по відношенню до свого природного і соціального оточення [14, с. 141]. Тому історик змушений використовувати моральні категорії і поняття, закріплені у побутовій мові. Хіміки, філологи чи соціологи більше схиляються до 
кількісних методів дослідження, застосовують нейтральні в моральному плані терміни. Особливість узагальнень історика полягає у тому, що оцінки (моральні, політичні, естетичні й ін.), які вони несуть в собі, внутрішньо притаманні предмету його вивчення, а не $є$ чимось зовнішнім щодо нього, як у природничих науках $[4$, с. 227,258$]$.

За А. Данто, навіть наявність чітко визначеної моральної позиції автора у творі не зменшуе наукової ваги історичної праці. Не можна не зважати на присутність часто свідомих прагматичних мотивів дослідника в написанні історії (бажання відновити чи підірвати чиюсь репутацію, викласти моральні настанови), однак це зовсім не суперечить його намаганню повідомити про те, що ж насправді відбулося. Якщо історик до цього не прагне, то він пише не історію [7, с. 133-134].

Отже, точка зору, оцінка $є$ невід'ємним структурним компонентом історичного нарративу. Вона певним чином визначає перспективу дослідження, тому безпосередньо відображена в історичній праці. Остання сама по собі $є$ точкою зору, оцінкою минулого $з$ позиції сучасності.

Таким чином, на нашу думку, найбільш загальна теоретична модель історичного нарративу складається 3 наступних елементів: смислової структури (композиційна та смислова організація матеріалу), літературної форми (об'єктивація й текстуальна організація інформаціï) і точки зору чи оцінки (відображкає та одночасно задає перспективу розгляду теми, питання).

\section{5 Бібліографія}

[1] Баксанский O.E., Кучер Е.Н. Познание познания: когнитивные науки // Эпистемология и философия науки. - 2007. - № 1.C. $148-169$.

[2] Берк П. Історія подій і відродження нарративу // Нові перспективи історіописання. Пер. $з$ англ. - К.: Ніка-Центр, 2004.

[3] Берлии И. Понятие научной истории // Берлин И. Подлинная цель познания. Избранные эссе / Пер. с англ. и комментарии B.В. Сапогова. - М.: Канон+, 2002.-C.25-80.

[4] Берлин Н. Историческая неизбежность // Берлин И. Подлинная цель познания. Избранные әссе / Пер. с англ. и комментарии B.В. Сапогова. - М.: Канон+, 2002. - С. 162-260. 
[5] Вен П. Как пишут историю. Опыт эпистемологии. (Приложение) - Фуко совершает переворот в истории:- М.: Научный мир, 2003.

[6] Газнюк Л.М. «Філософія нарративу» в персональному бутті людини // Філософська думка. - 2004.- ․ 4. - С. 3-15.

[7] Данто А. Аналитическая философия истории. Перевод с англ. А.Л. Никифорова, О.В. Гавришиной. - М.: Идея-Пресс, 2002.

[8] Игәерс Г.Г. История между наукой и литературой: размышления по поводу историографического подхода Хайдена Уайта // Одиссей: Человек в истории / РАН. Институт всеобщей истории. - М.: Hayкa, 2001.- C. 140-154.

[9] Каримов А.Ө. Кадастровая картография XVIII - начала XX вв. как форма социального диалога // ИИЕТ РАН. Годичная научная конференция. - 2003. - М.: Диполь-Т, 2003.- С. 44-50.

[10] Коллингвуд Р.Дж. Идея истории. Автобиография. - М.: Наука, 1980.

[11] Juоmap ЖК.-Ф. Состояние постмодерна. Перевод с фр. Н.А. Шматко. - М.: АЛЕТЕЙЯ, 1998.

[12] Лотман Ю.М. Внутри мыслящих миров // Лотман Ю.М. Семиосфера.- С.-Петербург: Искусство-СПЬ, 2000.- С. 150-391.

[13] Мегил A. Нарратив и четыре задачи историописания // Мегилл А. Историческая эпистемология: Научная монография (перевод Кукарцевой М., Кашаева В., Тимонина В.).- М.: Канон+, 2007. C. $199-254$.

[14] Мизес Л. Теория и история: Интерпретация социально-экономической эволюции / пер. с англ. А.В.Куряева.- Челябинск: Социум, 2007.

[15] Никитии B.E. Проблема исторической реальности // Метафизические исследования. Выпуск 2. История. Альманах Лаборатории Метафизических Исследований при Философском факультете СПбГУ, 1997. - С. 47-59. 
[16] Опарина E.O. Дискурс, речь, речевая деятельность: функциональные и структурные аспекты: Сб. обзоров / РАН ИНИОН. Центр гуманитарных научно-информационных исследований. Отдел языкознания; Ред. кол.: Ромашко С.А., отв. ред и др.-М., 2000. - C. 152-170.

[17] Папуша I. «Що таке наратологія?» (Огляд конщепцій) / Наративні виміри літератури. Матеріали міжнародної конференції 3 нарратології. Тернопіль, Україна, 23-24 жовтня 2003 р. // Studia methodologica. Вип. 16. - Тернопіль: Редакційно-видавничий відділ ТНПУ, 2005. - С. 29-45.

[18] Петренко Н.С. К проблеме нарратива в методологии истории // Философские науки. - 2000. - אa 1. - С. 108-116.

[19] Рикер П. Время и рассказ. Т. 1. Интрига и исторический рассказ. - СПб.: Университетская книга, 1998.

[20] Cenup Э. Избранные труды по языкознанию и культурологии. M., 1993. - C.259-265.

[21] Уайm X. Метаистория: Историческое воображение в Европе XIX века. - Екатеринбург: Изд-во У рал. ун-та, 2002.

[22] Уорф Б.Л. Наука и языкознание. О двух ошибочных воззрениях на речь и мышление, характеризуюших систему естественной логики, и о том, как слова и обычаи влияют на мышление // Зарубежная лингвистика. I, М., 1960. - С.92-106.

[23] IIмид B. Нарратология. - М.: Языки славянской культуры, 2003. 